\title{
Oil from bombed plant left to spill
}

The environment has been caught in the crossfire between Israel and Lebanon. So far, 15,000 tonnes of fuel oil has leaked into the Mediterranean Sea from Lebanon's bombed Jiyyeh power plant, 30 kilometres south of Beirut.

With more than 100 kilometres of the Lebanese coastline, and 10 to 20 kilometres of Syria's coast now affected, biologists are scrambling to try to assess how much damage the Lebanese spill could do, and how best to contain it.

"Every oil spill is different," says Robin Crump, a marine biologist who was involved in the clean-up operations after a 1996 spill off the coast of Wales. "Everything depends on the type of oil, the temperature of the water and the air, the intertidal regions."

Satellite images show that most of the fuel oil leaked by the Jiyyeh plant has been pushed to the Lebanese shore by southwesterly winds; the lack of wave action in the Mediterranean has meant the slick has not been broken up.

Although thick oil such as Jiyyeh's is less immediately toxic to wildlife, it can cause problems in the long term. It can pick up sand and sediment from beaches and the mix can then be carried offshore and sink, spreading the oil over a wider area. Warm temperatures can also bake it into a biologically inert crust, like tarmac, that protects the fresher oil underneath from breakdown by bacteria.

Although the Lebanese government has received international aid in the form of floating barriers and barrels of detergent to help combat the slick, clean-up has not yet begun. Part of the problem is that no emergency experts from outside the country have been granted security

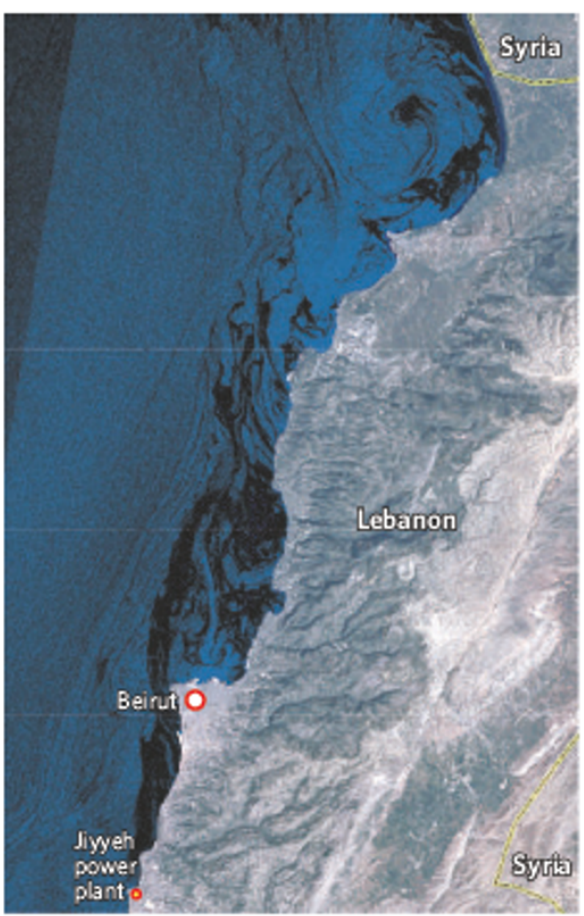

A satellite image shows the extent of an oil slick, spilled froma bombed power plant in Lebanon.

clearance to conduct an impact assessment. And even if experts are given access, the conflict will make it hard to recruit locals to help clean the beaches, observers say.

An untreated spill can cause lasting harm, says Jacqueline Michel, president of Research Planning, an environmental-management firm based in Columbia, South Carolina. During the first Gulf War in the early 1990s, oilfields were sabotaged and some 1.5 million tonnes of crude oil spilled into the Persian Gulf. Most of it ended up on the Saudi Arabian coastline, and only around $10 \%$ was ever recovered. Today, Michel says, "the intertidal communities have shown little or no recovery".

In Lebanon, the failure to mount a swift clean-up operation could most harm the region's threatened leatherback, loggerhead and green turtles. Bluefin tuna may also be at risk depending on where theoil goes, adds Luisa Colasimone of the United Nations Environment Programme. The eastern Mediterranean is home to a large spawning ground for the tuna.

Environmental damage can occur even after a hasty clean-up, says Charles Peterson, a marine ecologist at the University of North Carolina, Chapel Hill. He and his colleagues have studied the long-term effects of an oil slick spilled when the Exxon Valdez tanker ran aground in Alaska's Prince William Sound in 1989. In 2003 they reported that the recovery of whale, otter and duck populations at the site of the spill has been slower than expected owing to indirect effects of oil contamination (C. H. Peterson et al. Science $302,2082-2086 ; 2003$ ). And a spill along the eastern coast of Panama caused extensive damage to the region's mangroves, despite efforts to minimize the impact of the slick.

On the other hand, some areas affected by spills bounce back relatively quickly. The 1996 spill off Wales is a case in point. "Ten years on, the system has recovered," Crump says.

Kerri Smith

With additional reporting by Michael Hopkin \section{.}

\section{Plan for postdoc union sparks backlash}

Postdocs at the University of California, one of the most influential US university systems, are embroiled in a debate over whether they should unionize. Some back the action, saying it would give them much-needed leverage for improving their working conditions. But others are concerned about the way in which the union in question - United AutoWorkers (UAW) - has recruited people to the cause.

If formed, the group would be only the second postdoc union in the country, and by far the largest. The University of Connecticut Health Center in Farmington has had one since 2004, and it cur rently represents 125 postdocs. At the University of California, the UAW would act for some 5,800 postdocs.

UAW representatives, including graduate students and postdocs at the university, have gone from lab to labcollecting signatures in support of unionizing. The organization filed a petition to represent postdocs on 13 July. Thismonth, some postdocs began a letter-writing campaign withdrawing their support, saying that they hadn't understood what was involved when they signed up.

The petition is waiting for the

California Public Employment

Relations Board to verify that all

the signatures are valid. If the UAW has signatures from more than half of the eligible members, the union will automatically be adopted. If $30-50 \%$ of postdocs have signed, a system-wide election will be held. If less than $30 \%$ have signed, no actionwill be taken.

UAW representative Maureen
Boyd says the union had a "strong majority" when it filed the petition. At present, it isn't clear whether postdocs can withdraw their support.

"Alot of people didn't feel they gotall the information they needed," says Gregory Potter, chair of the PostdoctoralScholars Association of the University of California, San Francisco. He says that the UAW resisted invitations to public discussions on the topic.

A decision on the union is likely to be reached in the nextfew weeks. Heidi Ledford 